\title{
6.4
}

\section{Wales: local government and politics}

Within Wales, local councils provide the main focus for democratic politics below the devolved government in Cardiff, and organise the provision of most local services. James Downe looks at how well they fulfil their roles.

\section{What does democracy require of local governments in Wales?}

Local councils should engage the wide participation of local citizens in their governance via voting in regular elections, and an open interest group and local consultation process.

$\downarrow$ Local voting systems should accurately convert parties' vote shares into seats on councils, and be open to new parties entering into competition.

$\downarrow$ As far as possible, consistent with the need for efficient scales of operation, local government areas and institutions should provide an effective expression of local and community identities that are important in civil society (and not just in administrative terms).

$\downarrow$ Local governments should be genuinely independent centres of decision-making, with sufficient own financial revenues and policy autonomy to be able to make meaningful choices on behalf of their citizens.

$\downarrow$ Local governments are typically subject to some supervision on key aspects of their conduct and policies by a higher tier of government. However, they should enjoy a degree of constitutional protection (or 'entrenchment') for key roles, and an assurance that cannot simply be abolished, bypassed or fully programmed by the Welsh government in Cardiff.

$\downarrow$ The principle of subsidiarity says that policy issues that can be effectively handled in decentralised ways should be allocated to the lowest tier of government, closest to citizens. 


\section{Recent administrative developments}

As elsewhere in the UK, the impact of austerity was the biggest challenge facing Welsh local government. Councils are responsible for $28 \%$ of Welsh public service expenditure. Yet local authority revenue fell substantially between 2009-10 (the last year of Labour government at Westminster) and 2016-17 (the first year of the May government). At a time of great uncertainty, Welsh councils had to make tough decisions about where to devote scarce resource and considered new ways to deliver services to people. Figure 1 shows that spending on education and social services were largely protected, where cuts above $40 \%$ were made to environment and planning and community support, and $70 \%+$ cuts in economic development spending.

Figure 1: Cuts to net current service spending by service in Wales, 2009-10 to 2016-17 (at constant 2017-18 prices)

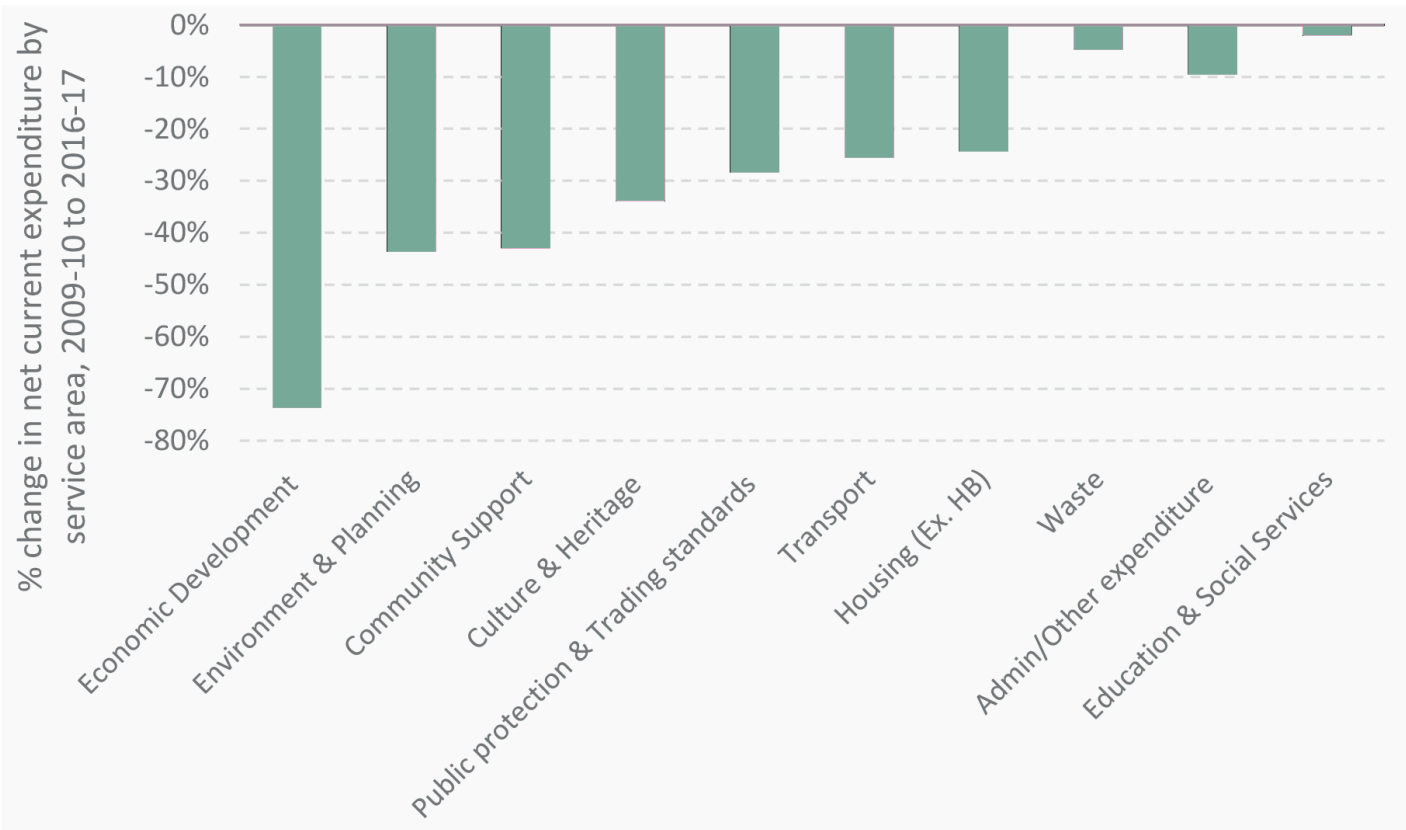

Source: Ogle et al, 2017

The ongoing squeeze on local spending in large part accounts for the repeated controversies over replacing the current structure of 22 local councils in Wales with a 'streamlined' structure of ten or fewer councils. First proposed by a 2014 Commission, this idea was live in 2014-16, when the Welsh government dropped reorganisation proposals in favour of the existing councils simply co-operating more on services on a regional basis. However, in 2018 a similar plan was once again floated to save money (see below), but a comprehensive merger plan was dropped again.

The Brexit process is also likely to have implications for Welsh public services. Wales has received a good deal of funding from the European Union, amounting to £1.8bn in 2007-13. 
It is also still due a further $£ 2$ bn from EU structural funds in the period $2014-20$. Yet the country nonetheless voted to Leave (52.5\%) in the June 2016 referendum. Without access to the EU's regional funding, it remains to be seen how councils will fare. Pessimistic voices suggest that poor outcomes are likely.

\section{Recent political developments}

Politically, many south Wales councils were historically dominated by Labour, reflecting its dominance of Welsh government (see Chapter 6.3) and politics at a national level. In 2017, independents formed the second largest set of councillors after Labour, followed by Plaid Cymru and then the Conservatives and Liberal Democrats in clear fourth and fifth place. The plurality rule voting system (first-past-the-post) in local elections assigned Labour disproportionately more seats than votes, and they still control nine councils. Most other councils are controlled by a coalition, reflecting Wales's multi-party system and the importance of independent councillors. With effectively five parties (including independents) competing in most areas, plurality rule voting operated fairly proportionally (with a deviation from proportionality or DV score of 11\%), advantaging Labour and disadvantaging the Conservatives, but only moderately at an all-Wales level.

Figure 2 shows that in the May 2017 local elections (held before Jeremy Corbyn's bounce back at the general election) Labour's vote share fell appreciably (down 4.5\%) and they lost 112 councillors and control of three councils (Blaenau Gwent, Bridgend and Merthyr Tydfil), but retained control of seven. The Conservatives gained nearly $19 \%$ of votes, added 80 more councillors, becoming the second largest political party (but behind the independents) and winning control of a council (Monmouthshire). Plaid Cymru came third with one in six votes, increased their councillors (by 38) and also gained control of one authority (Gwynedd). The Liberal Democrats' vote share fell below 7\% and they lost ten councillors. The deviation from proportionality (DV) score fell a little to $9 \%$, a good result by UK standards.

Figure 2: The outcomes of the 2017 and 2012/13 local government elections in Wales

\begin{tabular}{|l|r|r|r|r|r|r|}
\hline \multicolumn{1}{|c|}{2017} & \multicolumn{2}{|c|}{$\mathbf{2 0 1 2 / 1 3}$} \\
\hline & votes\% & seats & seats\% & votes\% & seats & seats\% \\
\hline Labour & 30.4 & 468 & 37.3 & 34.9 & 580 & 46.3 \\
\hline Independents & 22.5 & 309 & 24.6 & 23.8 & 300 & 23.9 \\
\hline Conservative & 18.8 & 184 & 14.7 & 12.5 & 104 & 8.3 \\
\hline Plaid Cymru & 16.5 & 208 & 16.6 & 16.0 & 170 & 13.6 \\
\hline Liberal Democrats & 6.8 & 63 & 5.0 & 8.0 & 73 & 5.8 \\
\hline Others & 4.9 & 22 & 1.8 & 4.8 & 28 & 2.2 \\
\hline Total & 100 & $\mathbf{1 , 2 5 4}$ & 100 & 100 & $\mathbf{1 , 2 5 4}$ & 100 \\
\hline
\end{tabular}

Source: The Elections Centre

Note: In 2012, elections were held in all Welsh local authorities except Anglesey, where they were held in 2013. The figures listed are the total of both years. In 2017, elections were held for all 22 local authorities. 


\section{Strengths, Weaknesses, Opportunities, Threats (SWOT) analysis}

\section{Current strengths \\ Compared with other EU countries, the ratio of councillors to the electorate in Wales is relatively high, and the traditional council areas are relatively local and well- understood.}

Councils make significant efforts to keep councillors and the public informed of their decisions (but see below).

\section{Current weaknesses}

The public are still largely unaware of who makes decisions and how. Citizens are often reluctant to get involved in local politics, unless an issue directly affects them. Only around one in ten or 12 citizens contacts their council in any given year, although this ratio is higher in rural areas.

Critics argue that the 1,254 Welsh councillors are disproportionally 'pale, male and stale'. Studies show that most are over 60 years of age, and 99 in every 100 are white. Amongst those elected in 2017 just over a quarter $(28 \%)$ are women (compared to a third in England). A Welsh government push for greater diversity has not improved matters much.

The introduction of the 'cabinet' system in local government has made clearer where responsibility for decisions lies (at least internally) - either with an individual portfolio holder, a senior officer with delegated powers, the cabinet as a collective, or the council leader.

Local authorities have a generally good working relationship with the Welsh government, which has recognised that they 'do not need to manage the detail of local authority business. We can, and should, leave more autonomy and decision-making with those who manage the delivery of services,' (p.12).
Despite its commitment to less micromanaging, the Welsh government in Cardiff has outlined several overly prescriptive actions such as insisting that a councillor should hold at least hold four surgeries a year (which they have now backed down on). Critics accept that the Welsh government must continue to make strategic decisions, but argue that it should allow local authorities the power to decide how they deliver things.

Despite a Welsh government commitment to putting 'the citizen at the centre' of public service delivery, there has been no clear and coherent strategy for encouraging citizen engagement with local services. Webcasting meetings and budget meetings have proved unappealing to an issue-focused public who want to be involved at an earlier stage of policy-making. Councils have been slow to use digital innovations to engage with the public. So digitally adept young people ('millennials') are being asked to engage with an antiquated system. 


\begin{tabular}{|l|l|}
\hline Current strengths & Current weaknesses \\
\hline & $\begin{array}{l}\text { Plenty of performance data has been } \\
\text { produced, but not in user-friendly formats } \\
\text { that enable the public to assess how well } \\
\text { their councils are doing. Frequent changes } \\
\text { in national performance indicators make } \\
\text { comparison over time impossible. The } \\
\text { Williams Commission (2014) concluded 'the } \\
\text { picture for too many of the public services in } \\
\text { Wales is poor and patchy'. }\end{array}$ \\
\hline $\begin{array}{l}\text { After a consultation exercise that produced } \\
\text { only 17 responses across the whole of Wales, } \\
\text { the Welsh government removed the statutory } \\
\text { duty on local authorities to collect national } \\
\text { strategic indicators. The data for } 2015-16 \\
\text { showed an overall picture of improvement } \\
\text { over } 2014-15, \text { with performance for 17 } \\
\text { indicators going up and twelve indicators } \\
\text { showing a decline. }\end{array}$ \\
\hline
\end{tabular}

\section{Future opportunities}

The 2015 Well-being of Future Generations Act aims to improve the social, economic, environmental and cultural well-being of Wales. It sets out a range of duties for councils to ensure that every decision they make takes account of the needs of future generations as well as the existing population.

A new, robust performance framework needs to be put in place to ensure that there is sufficient evidence for the public to understand how Welsh councils are performing. More needs to be done to design outcomes measures which are meaningful to the public and performance need to be benchmarked against councils beyond Wales.

\section{Future threats}

Only $15 \%$ of local government income is currently raised through council tax. Councils are likely to be forced to raise council tax faster than inflation. There is no clear political appetite for the reform of local government funding.

The new regional collaborative arrangements need to be scrutinised from the start.

Previous public service collaborations were not fully held to account. 


\begin{tabular}{|c|c|}
\hline Future opportunities & Future threats \\
\hline $\begin{array}{l}\text { A far greater variety of service delivery } \\
\text { models now exist in Welsh local government, } \\
\text { which include community trusts, local } \\
\text { authority trading companies, community } \\
\text { asset transfers, and mutuals. These span a } \\
\text { range of services including culture, leisure, } \\
\text { arts and adult education. They are likely to } \\
\text { increase in their use as councils explore the } \\
\text { opportunities provided by regionalisation. }\end{array}$ & $\begin{array}{l}\text { The Brexit process may be damaging to local } \\
\text { government in Wales, where disadvantaged } \\
\text { areas have received considerable regional } \\
\text { subsidies from the European Union which } \\
\text { will no longer be available. }\end{array}$ \\
\hline $\begin{array}{l}\text { Councils need to consider how the public } \\
\text { could help provide or co-produce services } \\
\text { in the future, but there also needs to be a } \\
\text { healthy dose of realism about the size and } \\
\text { potential of such involvement. Changing the } \\
\text { public mindset on who delivers services is } \\
\text { going to be a lengthy process. }\end{array}$ & \\
\hline $\begin{array}{l}\text { A new Local Government (Wales) Bill (see } \\
\text { below) will be introduced in } 2019 \text { to enable } \\
\text { voluntary mergers to take place. The } \\
\text { formation of these arrangements is currently } \\
\text { being discussed. }\end{array}$ & \\
\hline
\end{tabular}

\section{The overall health of local politics in Wales}

Some political scientists regard local elections as 'second-order' contests, because they are viewed by the public and media as being less important than other elections for the Welsh Assembly or Westminster general elections. Turnout rates for Welsh local government elections are generally quite high compared with other parts of the UK, touching $49 \%$ in 1999 and $44 \%$ in 2008, but with some lower scores (42\% in 2004, and 39\% in 2012). (For comparison, general election turnout was 66\% in 2015, and 69\% in 2017.) They have also compared well with the Assembly turnouts.

In 2017 and 2012 one in twelve councillors (8\%) were elected unopposed, a somewhat higher proportion than in other parts of the UK. In one ward in Powys, there were no candidates and a by-election had to be held at a later date. Amongst town and community councils (which work on a micro-local scale within local authorities) only one in four are elected in contested races. Around a third of councillors elected in 2017 were new to the role, and there are many independents operating without any party organisation back-up, primarily representing their ward or community interests.

Welsh politics is multi-party, and in addition Figure 2 above shows that at the local level 'independent' councillors were the second largest group, especially so in rural areas. As elsewhere, the plurality rule electoral system produces some distortions. In 2012, Labour 
gained around $46 \%$ of the councillors with a vote share of just under $36 \%$. In 2017 , a vote share of just over $30 \%$ gave the party more than $37 \%$ of seats. For the Conservatives in Wales, operating lower down the pecking order of parties, the relationship between the share of the vote and the number of councillors is not so favourable. In 2012, they achieved a $12.5 \%$ vote share which delivered around $8 \%$ of seats. And in 2017 , a vote share of nearly $19 \%$ gave them under $15 \%$ of seats.

The Welsh government have recently consulted on introducing a range of reforms to modernise electoral arrangements including the proposal to allow councils to decide whether they would like to introduce the single transferable vote (STV) system for their local elections (used in Scottish council elections) in place of first-past-the-post. Labour-controlled councils are unlikely to opt for changes, but where and if it happens, Scotland's experience suggests that the introduction of STV would be a substantial reform. The Welsh government is also proposing lowering the voting age to 16 for the council elections in 2022.

Councils could clearly do more to engage citizens. Only $20 \%$ of the public agreed that they can influence decisions affecting their local area in a recent survey (Welsh Government, 2017). While cabinets formally meet in public, decisions are generally made behind closed doors in political group meetings. So at one level there is always clear agreement in public, but on the other hand real decision-making takes place elsewhere in party groups. The continuing prominence of 'independents' may raise issues of whether these councillors take a strategic view across the whole council (and increasingly, the whole of a wider region) rather than focusing on being local community concerns.

\section{Local government area reforms}

There has been much debate about whether the 22 local authorities in Wales are too small for the effective delivery of public services. A total of three Welsh government White Papers in as many years have all examined options to reform local government (Welsh Government, 2014; 2015; 2017). In 2014, the Welsh government's Commission on Public Service Governance and Delivery (known as the Williams Commission) recommended that councils should be merged to cut their number down to 10 or 12 . The latter option was initially favoured by the Welsh government. But in 2015, they introduced a Bill which contained proposals for creating only eight or nine councils.

However, the government in Cardiff was unable to gain enough political support to implement their reorganisation plans, either in the Welsh Assembly or within the local government sector. In 2016 the new Cabinet Secretary for Finance and Local Government scrapped the plans, and in their place advocated a more collaborative approach. The existing 22 councils would be retained but would be grouped on a regional basis to work together in providing key services. The Welsh government outlined a menu approach in 2017 allowing councils to choose the most appropriate scrutiny mechanism for the new regional structures.

But then, despite the previous record, in spring 2018, the Welsh government suddenly resurrected the idea of merging councils and offered councils three options in a Green Paper: voluntary mergers; phased mergers; or a single comprehensive programme of mergers, so as 
to cut them down to just ten authorities. The consultation process revealed little support for fundamental reform and the Welsh government has gone back to the drawing board (again) by setting up a working group to find common ground and a plan for change.

\section{Conclusions}

Critics argue that a successful balance has not yet been struck between the top-down direction from the Welsh government and Assembly and the policy discretion that local councils need. Cardiff ministers' approach to local authority reform continues to be 'topdown', confused and inconsistent. Letting councils decide on different mechanisms of holding decision-makers to account, as well as on different voting systems, is likely to be confusing for citizens and prevent reforms happening where they were most needed. For example, it seems very unlikely that Labour-dominated councils over long periods will adopt STV voting, although that may be where a change would yield most benefits in reducing electoral disproportionality. If the current Welsh councils can survive, they will clearly have to try and 'join-up' behind the scenes and with other services (like the NHS) so that the public's experience of services is not adversely affected.

James Downe is Professor in Public Policy and Management in the Wales Centre for Public Policy at Cardiff University (www.wcpp.org.uk). 